\title{
$\mathrm{HPA}$ 의 비선형 위상 왜곡을 고려한 타입기반 군 지연 등화기
}

김 용 국*, 조 병 각*, 백 광 훈, 유 흥 균

\section{Type-Based Group Delay Equalizer \\ Considering the Nonlinear Phase Distortion of HPA}

\author{
Yongguk Kim*, Byung Gak Jo*, Gwang Hoon Baek ${ }^{*}$, Heung-Gyoon Ryu \\ 요 약
}

본 논문에서는 비선형 전력증폭기(PA:power amplifier)의 AM/PM 비선형 왜곡특성을 포함하는 군 지연을 보 상하는 새로운 등화기를 제안한다. 군 지연 특성은 각 주파수 성분에 따라 서로 다르게 나타나는 상수가 아닌 비 선형 시간지연이다. 전력증폭기에서 발생되는 $\mathrm{AM} / \mathrm{PM}$ 특성으로 인한 위상 왜곡 현상은 군 지연을 증가시키는 주요한 요인이다. 이러한 군 지연 왜곡으로 신호 성상도에서 신호는 퍼지면서 회전하게 된다. 위와 같은 문제점 을 고려하여 각 주파수 성분에 따라 다르게 나타나는 비선형 시간지연을 정적인 군지연으로 구분하고, $\mathrm{PA}$ 의 $\mathrm{AM} / \mathrm{PM}$ 특성인 입력신호 크기에 따라서 위상 천이가 다르게 발생하는 것을 동적인 군 지연으로 구분한다. 정적 인 군 지연은 주파수 영역에서 Type-Based 방법으로 위상 왜곡을 추정 및 보상하고 동적인 군 지연은 시간영역 에서 위상회전을 보상한다. 제안된 군 지연 보상기법으로 전력증폭기의 $\mathrm{AM} / \mathrm{PM}$ 특성을 포함한 군 지연 특성을 충분히 보상할 수 있음을 확인하였다.

Key Words : static group delay, dynamic group delay, equalizer, AM/PM.

\section{ABSTRACT}

In this paper, we propose a novel equalizer to compensate for the group delay including AM/PM nonlinear distortion characteristics by the nonlinear power amplifier (PA). The group delay characteristic is a nonlinear non-constant time delay that appears differently depending on each frequency component. The phase distortion by $\mathrm{AM} / \mathrm{PM}$ characteristics arising from the power amplifier is a major factor to increase group delay. By the group delay distortion, the signal in the constellation expands and is rotated. Considering the problem mentioned above, the nonlinear time delay that appears differently depending on each frequency component is classified as a static group delay and AM/PM characteristic of PA, the different phase transitions depending on the size of input signal as a dynamic group delay. Static group delay estimates and compensate for phase distortions in the frequency domain with type-based method and dynamic group delay compensates for phase rotation in the time domain. We confirmed that the group delay compensation techniques were enough to compensate the group delay characteristics including AM/PM characteristics of the power amplifier.

\footnotetext{
※ 본 연구는 2012년도 국방과학연구소의 위탁연구비 지원에 의해 수행되었다(계약번호 UD110028ED).

- 주저자 : 충북대학교 전자공학과, coolfeelyg@naver.com, 준회원

교신저자 : 충북대학교 전자공학과, ecomm@cbu.ac.kr, 정회원

* 국방과학연구소

논문번호 : KICS2012-06-284, 접수일자 : 2012년 6월 19일, 최종논문접수일자 : 2012년 9월 19일
} 


\section{I. 서 론}

군 지연(Group Delay)은 신호가 아날로그 소자를 통과할 때 발생한다. 특히 군 지연은 필터를 통과 할 때 가장 큰 영향을 받기 때문에, 필터로 인해 발생되는 군 지연에 대해서 많은 측정 분석이 되어 왔다 ${ }^{[1]}$. 또한 안테나나 다른 요소에 의해 발생되는

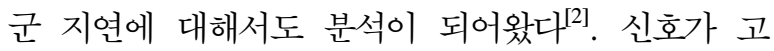
속화 되고 대역이 넓어지면서, 넓은 주파수 대역에 걸쳐 분포한 단일 반송파 신호는 주파수에 따라 파 장의 길이가 달라지는 영향을 받게 된다. 다시 말 해, 신호의 주파수에 따라 같은 지연이 발생하더라 도 파장의 길이가 달라지게 되어 주파수마다 서로 다른 위상변화가 발생하는 것을 의미한다. 더욱이 각 주파수마다 아날로그 소자 통과 시간이 다르게 발생하는 경우 군 지연으로 인한 수신 성능 저하는 더 크게 나타난다. 실제 군 지연이 문제가 되는 이 유가 이와 같이 고주파와 저주파가 서로 다른 지연 을 갖기 때문이다. 이런 주파수에 따른 다른 지연 크기, 다른 파장의 길이로 발생되는 군 지연의 영향 은 수신 단에서 위상 변화의 크기 차이로 나타나게 되어 성능을 저하시키게 된다.

군 지연에 대한 보상 방법은 아날로그 회로를 이 용한 방법이 주로 연구되어 왔다. 아날로그 방식은 군 지연의 특성을 주파수에 따라 일정하게 변화시 켜줄 수 있는 필터를 제작해 보상하는 것이다 ${ }^{[3]}$. 또 한 디지털 영역에서 필터를 제작해 신호의 위상만 을 보상해주는 방법이 연구되었다 ${ }^{[4]}$. 필터뱅크 방식 은 서브밴드 별로 위상을 회전시켜 보상하는 방식 으로 주파수에 따라 다르게 변화하는 위상은 보상 이 가능하다. 하지만 이러한 필터뱅크 방식은 하드 웨어적으로 많은 가격부담과 크기 문제가 발생한다 [5]. 또 다른 디지털 처리 방식의 다른 방법으로 모 델링을 통해 사전왜곡을 이용해 전송하는 방식도 제안되었다 ${ }^{[6]}$. 이 방식은 송신부에서 군 지연의 위 상 추정 계수를 피드백 하여 사전왜곡을 하는 방식 이다 ${ }^{[7-8]}$. 그러나 기존의 군 지연 보상에 관한 연구 에서는 $\mathrm{PA}$ 의 비선형 특성에 의해 발생되는 $\mathrm{AM} / \mathrm{PM}$ 왜곡 특성을 고려하지 못한 단점을 가지고 있다. 군 지연은 주로 필터, 안테나 등 여러 아날로 그 소자를 통과하면서 발생하기 때문이다 ${ }^{[9]}$. 따라서 $\mathrm{PA}$ 의 비선형 특성으로 발생하는 $\mathrm{AM} / \mathrm{PM}$ 왜곡 또 한 군 지연을 증가시키는 중요한 요인이 된다. 그렇 기 때문에 이러한 문제를 고려하여 $\mathrm{PA}$ 의 $\mathrm{AM} / \mathrm{PM}$ 왜곡 특성을 포함한 군 지연 보상방법에 대한 연구
가 필요하다.

$\mathrm{PA}$ 에서 발생하는 심각한 문제는 진폭 왜곡과 위 상 왜곡 두 가지가 있다. 진폭 왜곡은 입력 신호에 따라서 출력 신호에 왜곡이 생기며, $\mathrm{AM} / \mathrm{AM}$ 왜곡 이라고 한다. 위상 왜곡은 입력 신호 크기에 따라서 위상 천이가 발생하는데 이를 $\mathrm{AM} / \mathrm{PM}$ 왜곡이라고 한다. 이러한 위상 왜곡은 동적인 군 지연을 발생 시킨다. 이 때 PA에 의한 위상 천이는 수신 단의 LNA(low noise amplifier)보다 송신 단의 PA에서 크게 발생하기 때문에 송신 단의 $\mathrm{PA}$ 만을 주로 고 려한다. $\mathrm{PA}$ 의 $\mathrm{AM} / \mathrm{PM}$ 특성을 포함하는 군 지연에 의해 발생되는 위상 왜곡은 그 현상이 주파수와 입 력 신호의 크기에 따라 달라지는 특성을 가지고 있 어 각각에 대한 분석 보상이 필요하다. 그리고 군 지연에 의한 위상 회전은 전송 대역, 대역 폭, modulation 방식이 정해져 있다면 시간에 따라 변 하지 않는 수치이므로 시스템 제작 과정에서 설계 가 가능하다. $\mathrm{PA}$ 의 $\mathrm{AM} / \mathrm{AM}, \mathrm{AM} / \mathrm{PM}$ 특성 곡선에 대한 여러 가지 이론적인 모델링 방법이 제시되어 있다 본 논문에서는 대표적인 모델링 방법 중 Saleh 가 제안한 TWTA 모델을 기반으로 하였다.

\section{II. 군 지연 특성 분석}

군 지연은 신호가 필터와 같은 아날로그 소자를 통과할 때 발생하는 시간 지연을 나타낸다. 선형 위 상 응답 $\theta=-\beta_{0} \omega$ 에 대해 상수 $\beta_{0}$ 의 군 지연이 발생한다. 하지만 비선형의 위상 응답이 발생하게 되면, 신호의 모든 주파수 성분이 각기 다 른 시간 지연을 가지게 된다.

$$
\operatorname{Group} \operatorname{Delay}(G D)=-\frac{\partial \theta}{\partial \omega}
$$

군 지연의 표현은 식 (1)과 같으며, 각 주파수

$\omega$ ( $2 \pi f$ )에 따른 위상의 변화량 ( $d \theta$ )을 의미한다. 여기서 $\theta$ 는 전체 위상회전이며, $\omega$ 는 시간에 따른 각 진동수이다. 식 (1)을 정리하면, 위 상의 크기 변화는 주파수와 군 지연에 의하여 결정 된다. 군 지연은 주파수에 따라 일정한 시간 지연의 형태가 아닌 2차/3차식으로 표현된다. 그리고 군 지 연은 대역이 제한되는 지점에서 최대로 발생한다. 필터의 진폭 응답에서 천이 대역의 기울기 값 크기 에 따라 군 지연이 발생하는 크기가 달라지게 된다. 본 논문에서는 송신 신호를 Chebyshev2 필터를 통 
과시켜 군 지연을 발생시키고 필터의 차수, Roll-off factor, 저지 대역 리플 값을 달리하여 군 지연 크 기를 조절하였다.

대부분의 아날로그 소자는 군 지연 특성을 갖는 다. 따라서 전체 시스템에서 군 지연이 각각 발생할 수 있다. 그리고 정적인 군 지연은 3 차식의 형태로 식 (2)와 같이 모델링 될 수 있다.

$$
G D=\beta_{0}+2 \beta_{1} f+3 \beta_{2} f^{2}+4 \beta_{3} f^{3}
$$

각 소자의 군 지연을 고려한 전체적인 군 지연 모델은 다음 식과 같이 표현될 수 있다.

$$
G D=\left(a_{0}+b_{0}+c_{0}\right)+\left(a_{1}+b_{1}+c_{1}\right) f+\left(a_{2}+b_{2}+c_{2}\right) f^{2}+\cdots
$$

안테나, 필터, 전력 증폭기에 의해 군 지연이 발 생할 때, 각 군 지연 계수는 $a, b, c$ 로 설정 할 수 있다. 군 지연의 특성은 군 지연의 영향을 받은 신호가 크기의 감쇄 없이 위상의 영향만을 가 지고 발생하는 특징을 가진다. 더욱이 주파수의 변 화도 위상에 영향을 미친다. 따라서 시간 영역에서 정적인 군 지연을 추정하는 방법은 어렵기 때문에, 주파수 영역에서 정적인 군 지연을 추정하는 방법 이 효과적이다. 한편, $\mathrm{PA}$ 의 $\mathrm{AM} / \mathrm{PM}$ 특성은 입력 신호 크기에 따라서 동적인 군 지연을 발생시킨다. 그러므로 $\mathrm{AM} / \mathrm{PM}$ 특성을 고려한 군 지연에서는 신 호의 왜곡 정도가 더욱 심하게 나타난다. 시간 영역 입력 신호에 따라 변화하는 $\mathrm{AM} / \mathrm{PM}$ 특성에 의해 발생한 동적인 군 지연은 시간영역에서 보상하게 된다.

본 논문의 PA는 위성 통신 시스템에서 사용되는 고출력 증폭기 TWTA를 고려하였다. 그리고 TWTA의 비선형 특성은 파라미터 수가 적을 때에 도 정확한 모델링이 가능한 Saleh 모델을 사용한다. TWTA의 왜곡 특성은 비선형 입.출력 진폭 특성 $(\mathrm{AM} / \mathrm{AM})$ 과 비선형 입력 진폭 출력 위상 특성 $(\mathrm{AM} / \mathrm{PM})$ 으로 나눌 수 있다. 하지만 본 논문에서는 위상의 왜곡을 고려하기 때문에 $\mathrm{AM} / \mathrm{PM}$ 특성만을 고려한다. $\mathrm{AM} / \mathrm{PM}$ 왜곡 식은 (4)와 같다. $t$ 는 입 력 전압이고 $\alpha, \beta$ 는 TWTA 비선형 특성 상수이 다.

$$
z(t)=\frac{\alpha t^{2}}{\left(1+\beta t^{2}\right)}
$$

$\mathrm{TWTA}$ 의 $\mathrm{AM} / \mathrm{PM}$ 특성은 다음과 같은 계수로 모델링 된다: $\alpha=2.5293, \quad \beta=2.8168^{[20]}$. TWTA의 AM/PM 특성을 미리 알고 있는 상황에서 $\mathrm{AM} / \mathrm{PM}$ 특성을 제거 할 수 있다.

\section{AM/PM 왜곡 특성을 포하한 군 지연 등화기}

\section{1. 기존의 군 지연 보상기}

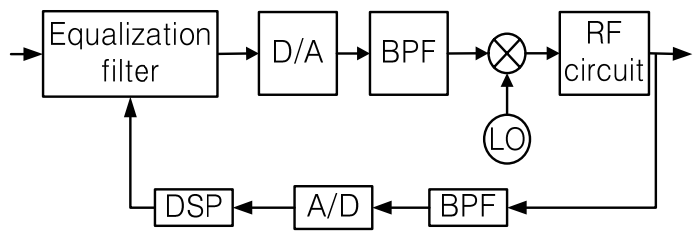

그림 1. 군 지연 보상을 위한 기존의 Type-Based기술. Fig. 1. Conventional Type-Based technique for compensation of GD.

아날로그 회로를 통한 시스템의 부담을 줄이기 위해서 디지털 처리를 통한 군 지연을 보상하는 방 법들이 제안되어 왔다. 그림 1은 Type-Based 기술 을 적용한 기존의 군 지연 보상 기술에 대한 블록 도이다. 기존의 방법은 송신 단의 $\mathrm{RF}$ 필터에서 발 생하는 신호에 대한 군 지연을 피드백 방식을 이용 해 전치왜곡의 방식으로 보상을 하였다. 기존의 Type-Based 방식은 다음과 같이 구성된다. 대역 내 군 지연 왜곡을 제거하기 위해, 등화필터의 주파수 응답은 $\beta$ 의 함수로서 추정된 파라미터 벡터 $C(f \mid \hat{\beta})$ 에 의해 (5)와 같이 표현된다.

$$
C(f \mid \widehat{\beta}) \cdot H(f \mid \beta)=\exp \{j 2 \pi \alpha f\}
$$

여기서 $\alpha$ 는 양의 상수이다. 추정된 신호는 군 지연의 영향과 곱했을 때, 1 차식을 갖는 위상 회전 을 가져야 한다. 회로의 군 지연 특성 $H(f \mid \beta)$ 는 식 (6)과 같이 표현될 수 있다.

$$
H(f \mid \beta)=\exp \left\{-j 2 \pi \sum_{k=0}^{K} \frac{1}{k+1} \beta_{k} f^{k+1}\right\}
$$


따라서 추정 $C(f \mid \hat{\beta})$ 는 식 (7)과 같이 표현 된다.

$$
\begin{aligned}
C(f \mid \beta) & =\frac{1}{H(\beta \mid f)} \exp \{j 2 \pi \alpha f\} \\
& =\exp \left\{j 2 \pi\left(\sum_{k=0}^{K} \frac{1}{k+1} \beta_{k} f^{k+1}+\alpha f\right)\right\} \\
& =\exp \left\{j 2 \pi \sum_{k=0}^{K} \frac{1}{k+1} \beta_{k} f^{k+1}\right\}
\end{aligned}
$$

식 (7)에서 마지막 af 은 전 식에 흡수되면 최종적으로 위와 같이 표현된다. 따라서 필터에 의 해서 발생하는 군 지연을 알기 위해서 $C(f \mid \hat{\beta})$ 를 찾아야 한다. 기존의 논문은 계수의 수를

$k$ 개로 정의하고 있으며, 반복 절차를 통해 회 로 출력 신호와 이상적인 신호 사이의 왜곡 측정의 최소값을 찾는다.

$$
\min _{\beta} \Delta(\widehat{\beta})=\min _{\beta}\left[\sum_{n=0}^{N}\left(P_{D}\left(a_{n}, \widehat{\beta} \mid \beta\right)-P_{\text {Ideal }}\left(a_{n}\right)\right)^{2} P_{\text {Ideal }}\left(a_{n}\right)\right]
$$

추정된 값 $\beta$ 는 식 (8)와 같이 찾는다. 필터 군 지연의 영향을 받은 신호를 피드백 해서 이상적인 신호와 비교하여 추정하게 된다. 여기서 $a$ 는 신 호의 진폭 크기이다. 이렇게 찾아진 신호는 식 (9) 와 같이 나타낼 수 있다.

$$
\frac{\partial \Delta(\widehat{\beta})}{\partial \widehat{\beta}_{k}}=0, \text { for } k=0,1, \ldots, K
$$

최소화를 갖는 $\Delta(\hat{\beta})$ 에 도달하기 위해서, 식 (9)는 0 의 값을 가져야 한다. $\hat{\beta}$ 는 각각의 $\mathrm{K}+1$ 개 에 대해서 독립적인 값을 가진다. 따라서 식 (10)은 위 식들을 이용해 나타낼 수 있다.

$$
\sum_{n=0}^{N} P_{\text {Heal }}\left(a_{n}\right)\left(P_{D}\left(a_{n}, \widehat{\beta} \mid \beta\right)-P_{\text {Iteal }}\left(a_{n}\right)\right) \cdot \frac{\partial P_{D}\left(a_{n}, \hat{\beta} \mid \beta\right)}{\partial \beta_{k}}=0
$$

기존의 방법에서는 반복을 통해 발생한 왜곡 문 제를 최소화 하게 된다. 그러나 기존의 시스템은 군 지연 발생을 송신 단 $\mathrm{RF}$ 필터에 대해서만 고려하였 고 $\mathrm{PA}$ 의 비선형 특성에 의한 $\mathrm{AM} / \mathrm{PM}$ 왜곡에 대해 서 고려하지 않았다. 그리고 아날로그 소자에서 발 생할 수 있는 군 지연의 특성을 수신 단을 제외한 송신 단에서만 고려하였다. 또한 군 지연 추정을 위 해 높은 차수까지 모델링하기 때문에 높은 복잡도 를 갖는다. 이러한 이유로 등화를 위해 필터를 사용 한 기존 방법은 실시간으로 데이터 처리가 어렵다. 필터에 의해서 발생하는 군 지연은 시간에 따라서 일정하기 때문에, 한번 계산으로 그 문제를 보상할 수 있다. 그러나 수신 단에서 발생하는 군 지연이 고려되지 않았기 대문에 추정하기 어렵고 문제를 정확히 정정하기 어렵다.

여기서는 소단원에 관한 내용을 간단히 살펴본다. 여기서는 소단원에 관한 내용을 간단히 살펴본다.

\section{2. 제안된 군 지연 보상기}

군 지연은 송.수신 단 모두에서 고려되어야 한다. 이는 송신 단부터 수신 단까지의 아날로그 소자에 의해서 발생하는 위상에의 영향으로 인해 시스템 전체의 군 지연을 고려하기 위해서는 수신 단에서 처리도 요구되기 때문이다. 또한 군 지연으로 인한 영향은 높은 차수의 식을 이용하지 않고도 추정 할 수 있다. Linear, Quadratic, Cubic모델은 각각 1차, 2 차, 3 차식으로 나타낼 수 있으며, 계수 $\beta$ 와 대 역폭 $B W$, 중심 주파수 $f_{\text {center }}$ 로 표현 할 수 있다 $\left(G D=(i+1) \beta_{i}\left(\frac{f-f_{\text {center }}}{B W}\right)^{i}\right.$,

여기서 Linear: $i=1$, Quadratic: $i=2$, Cubic: $i=3$ ). 전체 시스템의 군 지연은 계수 ' $\beta$, 를 갖는 모델 들의 합으로 식 (11)과 같이 표현된다.

$$
f \equiv \frac{f-f_{\text {center }}}{B W}
$$

군 지연을 적분하면 위상으로 변화시킬 수 있는 데, 변화된 위상은 식 (12)와 같이 표현할 수 있다.

$$
\theta(f)=-\left(\beta_{0} f+\beta_{1} f^{2}+\beta_{2} f^{3}+\beta_{3} f^{4}\right)
$$


만약 추정을 통해서 계수 $\beta$ 를 알고 있다면, 군 지연에 의해서 발생한 왜곡은 식 (13)와 같이 표현이 가능하다.

$$
\tilde{H}(f)=e^{i 2 \pi\left(\beta_{0} f+\beta_{1} f^{2}+\beta_{2} f^{3}+\beta_{3} f^{4}\right)}
$$

군 지연 보상을 위해서 수신된 신호와 모델링 된 신호의 곱은 1 이 되어야 한다.

$$
\tilde{H}(f) \cdot H(f)=1
$$

따라서 군 지연을 정확하게 추정하기 위해 계수 $\beta$ 는 중요하다. 본 절은 기존의 Type-Based 방식 을 이용해 정적인 군 지연을 보상하는 방식이다. 정 적인 군 지연은 시스템 설계 후에 고정된 위상 왜 곡을 발생시킨다. 따라서 Type-Based 방식을 이용 해 고정된 계수 $\beta$ 를 찾고, 고정된 계수 값으로 전체 시스템에서 아날로그 소자에 의해 발생한 군 지연을 보상한다. 또한 정적인 군 지연은 주파수에 따라서 다른 위상이 나타나는 특징이 있다. 그렇기 때문에 주파수 영역에서 군 지연을 보상하는 것이 효과적이다.

그림 2는 제안하는 군 지연 등화기 구조를 보여 준다. 주파수 영역에서 정적인 군 지연을 보상하는 것이 더 효과적이기 때문에 주파수 영역 등화기를 사용한다. 그 이유는 정적인 군 지연은 시간에 따라 변하지 않기 때문에 하드웨어 제작 시 고정된 추정 계수 $\beta$ 를 이용하여 보상할 수 있기 때문이다. 주 파수영역 등화를 위해 FFT를 이용해 시간영역에서 주파수 영역으로 신호를 변화 시킨다. 계수 $\beta$ 를 구하기 위해 프리앰블을 사용하고 반복해서 계산하 게 된다.

$$
\theta(f)=\operatorname{angle}\left(\frac{Y_{\text {received }}}{X_{\text {transmitted }}}\right)
$$

위상 왜곡에 의한 각도는 프리앰블을 사용해 식 (15)와 같이 추정한다. 여기서 $\mathrm{X}, \mathrm{Y}$ 는 FFT 후 주 파수 영역 신호이다. 그러므로 군 지연은 식 (15)로 부터 식 (16)과 같이 표현된다.

$$
G D_{\text {received }}=-\frac{d \theta(f)}{d f \cdot 2 \pi}
$$

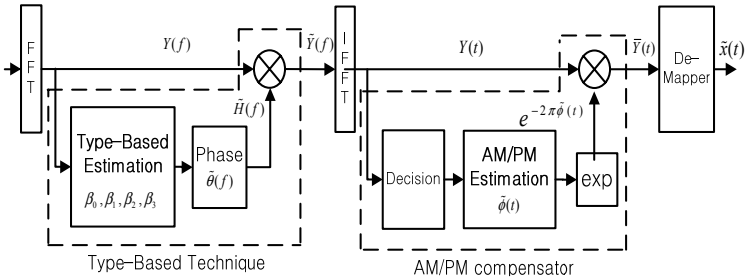

그림 2. 군 지연 보상을 위한 등화기의 구조.

Fig. 2. Equalizer structure for compensating group delay.

전체 시스템에서 군 지연이 발생하면, Linear/Quadratic/Cubic 모델 식과 같은 패턴을 가 지게 되나 차수의 간략화에 따른 리플이 발생하게 된다. 그러므로 리플을 최소화하기 위해 수신기는 신호를 반복적으로 받고 평균을 통해 군 지연을 측정한다.

$$
D=\left\{G D_{\text {received }}-\tilde{H}_{\text {group dely }}\right\}
$$

식 (17)는 왜곡 크기를 나타낸다. 그리고 수신 된 신호의 군 지연에서 계수 $\quad \beta$ 를 바꾸면서 추정된 군 지연을 뺀 값이다.

$$
\left[\beta_{0}, \beta_{1}, \beta_{2,} \beta_{3}\right]=\min \{\operatorname{var}(D)\}
$$

왜곡의 최소 변화 값은 식 (17)과 식(18)을 통 해 계산된다.

\section{3. $\mathrm{PA}$ 의 $\mathrm{AM} / \mathrm{PM}$ 특성에 의한 동적인 군 지연 보상기}

$\mathrm{PA}$ 의 $\mathrm{AM} / \mathrm{PM}$ 특성에 의한 동적인 군 지연은 입 력 신호의 크기에 따라서 다른 위상 회전을 갖는다. 입력 데이터는 추정할 수 없기 때문에 동적인 군 지연은 랜덤 특성을 갖는다. 따라서 그림 2에서 동 적인 군 지연은 IFFT 처리 후 시간 영역에서 프리 앰블을 이용한 추정을 통해 보상된다. $\mathrm{AM} / \mathrm{PM}$ 에 의한 위상 회전은 변조 시 mapping에 따라 다르기 때문에 입력 값에 따라 다른 각각의 위상회전의 각 도를 측정 할 수 있다. 그런 다음 입력 크기에 따 라 다른 위상회전의 정보를 가지고 동적인 군 지연 을 보상한다. 정적인 군 지연은 $16 \mathrm{APSK}$ 로 변조된 후 아날로그 소자에 의해 발생되기 때문에 신호의 성상도는 퍼지게 된다. 만약 정적인 군 지연을 갖는 
신호가 PA에 의해 영향을 받으면 성상도는 전체적 으로 회전하게 된다. 제안된 방식은 동적인 군 지연 의 위상 회전을 추정하기 위해서, 프리앰블을 통해 크기에 따른 위상 변화의 추정으로 구할 수 있다. 정적인 군 지연의 보상 후 $\mathrm{AM} / \mathrm{PM}$ 특성은 식 (19) 와 같이 Saleh 모델에 따라서 추정할 수 있다.

$$
\tilde{\phi}(t)=\frac{\alpha t(t)_{\text {decision }}^{2}}{1+\gamma t(t)_{\text {decision }}^{2}}
$$

이렇게 추정된 위상 변화 값을 이용하여 프리앰 블 이 후 입력되는 신호의 위상을 회전시키게 된다. 수신 부에는 무작위로 발생된 데이터가 입력되므로 입력되는 신호의 전압 크기를 알아야 한다. 따라서 정적인 군 지연에 의해 발생된 왜곡에 의한 동적인 군 지연 추정 에러를 최소화 하기 위해, 정적인 군 지연의 보상은 신호의 decision 전에 처리해야 한다.

$$
\bar{y}(t)=y(t) \cdot e^{-i 2 \pi \tilde{\phi}(t)}
$$

동적인 군 지연에 의한 위상 보상은 추정된 $\tilde{\phi}(t)$ 를 식 (20)과 같이 반대로 위상 회전시킴으 로써 위상왜곡을 보상할 수 있다.

\section{IV. 시뮬레이션 결과 및 분석}

본 논문의 전체 시스템에서 고려된 위상 문제는 정적인 군 지연에 의한 위상왜곡과 $\mathrm{PA}$ 의 $\mathrm{AM} / \mathrm{PM}$ 특성에 의해서 나타나는 동적인 군 지연의 위상회 전이다. 각각의 원인에 의해서 발생하는 왜곡을 추 정하기 위해 프리앰블을 사용하였다. 또한 $\mathrm{PA}$ 의 모 델은 위성 통신에서 쓰는 Saleh의 TWTA모델을 사 용하였다. TWTA모델은 AM/AM 왜곡과 AM/PM 왜곡이 존재하는데, 본 논문에서는 위상 회전에 의 해서 나타나는 성능 저하를 확인하기 위해 $\mathrm{AM} / \mathrm{PM}$ 왜곡만을 고려하였다. 위성에서의 채널 모델은 AWGN 채널만을 고려하였다. 본 논문에서는 송·수 신 단의 아날로그 소자에서 모두 군 지연이 발생하 는 환경에서 시뮬레이션을 진행하였다. 그리고 제안 된 등화기를 이용해 군 지연을 보상한 성능을 분석 하였다.

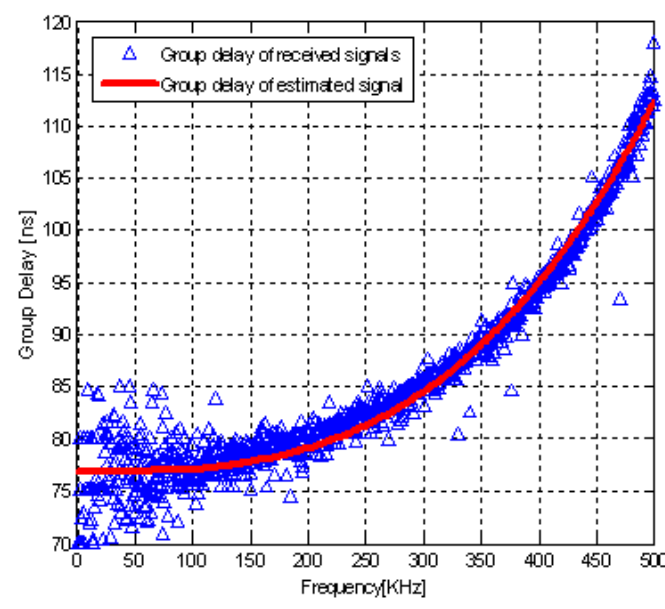

그림 3. 주파수 영역에서의 정적인 군 지연 추정 결과.

Fig. 3. Estimation of static group delay in frequency domain.

그림 3 은 정적인 군 지연의 추정 결과이다. 정적 인 군 지연은 주파수가 증가함에 따라 지연시간이 증가한다. 대역폭이 $1 \mathrm{MHz}$ 인 환경에서 신호를 전송 한다면 군 지연은 저주파 성분에서 $80 \mathrm{~ns}$ 보다 작게 나타나지만, 전송 신호의 고주파 성분에서는 약 $110 \mathrm{~ns}$ 이상의 군 지연이 발생하게 된다. 그림 3 에 서 군 지연 모델의 계수를 변경하면서 추정한 결과 로서 각각의 계수 값은 $\beta_{0}$ 가 $0.0233, \beta_{1}$ 이 $0.0002, \beta_{2}$ 가 $0.0001, \beta_{3}$ 가 0.0133 이다. 이것은 군 지연은 상수 값과 고차항의 성분이 낮은 차수보 다 추정 성능에 더 많은 영향을 미친다는 것을 알 수 있다. 또한 수신 신호는 군 지연 리플이 존재하 여 수신 신호에서 추정 모델의 계수를 찾는데 영향 을 미친다. 따라서 반복적인 수신을 통해 가장 시스 템과 비슷한 군 지연의 계수를 찾는다.

그림 4는 군 지연에 의해서 저하된 성능과 보상 후 성능을 보여준다. 시뮬레이션에서 $\mathrm{HPA}$ 의 back-off 값을 $5 \mathrm{~dB}$ 로 적용하였다. 그림에서 파란색 solid line은 보상 전의 BER 성능을, 빨간색 dashed line은 보상 후의 BER 성능을 나타낸다. a)는 정적 인 군 지연만 고려한 경우이고, $\mathrm{b}$ )는 그 것을 보상 한 결과이다. c)는 정적인 군 지연과 동적인 군 지 연을 함께 고려한 경우이고, d)는 c)모델에서 정적 인 군 지연만 보상한 결과이다. f)는 정적인 군 지 연과 동적인 군 지연을 모두 보상한 결과이다. a)와 c)를 비교해 보면 정적인 군 지연만 고려했을 때 보다 정적인 군 지연과 동적인 군 지연을 함께 고 
려했을 때 $\mathrm{BER}$ 성능이 크게 악화되는 것을 확인 할 수 있다. d)와 f)를 비교해 보면 정적인 군 지연 과 동적인 군 지연을 함께 고려한 모델에서 정적인 군 지연만 보상한 것 보다 동적인 군 지연을 함께 보상 했을 때 성능이 매우 좋아지는 것을 알 수 있 다.

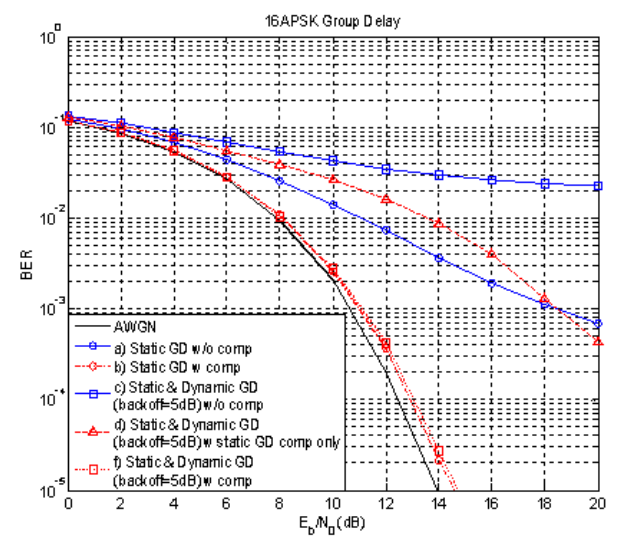

그림 4. 군 지연의 영향과 보상 결과.

Fig. 4. Effects and compensation results of group delay.

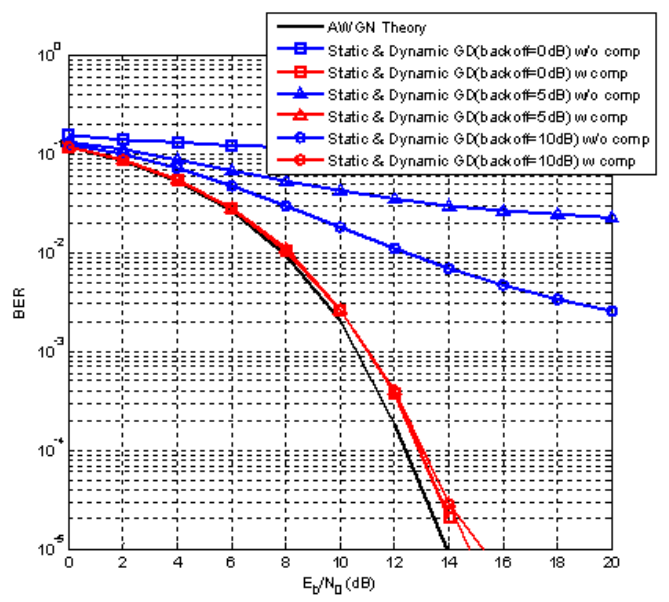

그림 5. Back-off 변화에 따른 Static 군 지연과 Dynamic 군 지연 영향과 보상.

Fig. 5. Effects and compensation results of static and dynamic group delay with back-off.

그림 5는 PA의 back-off에 따른 정적인 군 지연 과 동적인 군 지연의 $\mathrm{BER}$ 성능을 나타내었다. 성 능저하 정도는 군 지연과 $\mathrm{PA}$ 의 성능 저하가 더해 진 것과 비슷하며, 보상 후에는 약간의 차이만을 보 일 뿐 각각이 모두 보상된 것을 확인 할 수 있다.

\section{$\mathrm{V}$. 결 론}

본 논문에서는 무선 통신 시스템에서 군 지연 왜 곡을 보상하기 위한 동적인 군 지연 등화기를 제안
했다. 각 주파수에 따라서 다르게 나타나는 비선형 시간지연을 정적인 군 지연으로 구분하고, $\mathrm{PA}$ 의 $\mathrm{AM} / \mathrm{PM}$ 비선형 특성으로 입력신호 크기에 따라 위 상왜곡이 달라지는 군 지연을 동적인 군 지연으로 구분하였다. 정적인 군 지연만 고려했을 때 보다 동 적인 군 지연을 함께 고려했을 때 $\mathrm{BER}$ 성능이 매 우 악화된다. 정적인 군 지연은 시스템 제작 시 Type-Based 방법으로 추정한다. 그러나 동적인 군 지연은 입력 신호 크기에 따라 위상왜곡이 달라지 기 때문에 심볼마다 추정해서 보상해 주어야 한다. 정적인 군 지연만 고려했을 때 $\mathrm{BER}=10-5$ 에서 보상 후 성능은 $\mathrm{AWGN}$ 이론 값과 약 $1 \mathrm{~dB}$ 차이가 난다. 정적인 군 지연과 동적인 군 지연을 함께 고려한 경우 또한 보상 성능은 향상되었다. 그리고 $\mathrm{BER}=10-5$ 에서 시뮬레이션 결과 값은 $\mathrm{AWGN}$ 의 경 우와 비교할 때 약 $1 \mathrm{~dB}$ 차이를 갖는다. 동적인 군 지연은 back-off 크기에 따라 왜곡 정도가 달라지지 만 대부분 보상되었다. 결론적으로, 시뮬레이션 결 과 제안한 등화기는 효과적으로 동적인 군 지연과 정적인 군 지연을 모두 보상할 수 있음을 확인하였 다.

\section{References}

[1] S. Kahng, M. S. Uhm, S. P Lee, "A dual-mode narrow-band channel filter and group-delay equalizer for a ka-Band satellite transponder," ETRIJournal, Vol.25, no.5, pp.379-386, Oct. 2003.

[2] P.McEvoy, Matthias John, Sergio Curto, Max Ammann, "Group delay performance of ultra wideband monopole antennas for communication applications," Antennasand Propagation Conference, pp. 377-380, Mar. 2008.

[3] L. Zhao, P. Wang, Z. C. Zhang, J. P. Wang, G. J. Zhang, Z. Y. Li, "Design and simulation of a group delay equalizer circuit," Pervasive Computing Signal Processing and Applications (PCSPA), pp. 1302-1305, Sept. 2010.

[4] B. R. Barbosa, F. S. Adriano, "Robust and efficient algorithm for the design of stable group delay equalizers using constrained optimization Methods," 15th Annual Wireless Symposium, Lisbon, Portugal, 2005. 
[5] S. Weiss, D. Garcia-Alis, R. W. Stewart, "Adaptive equalization in oversampled subbands," Novel DSP Algorithms and Architectures for Radio Systems, IEE Colloquiumon, pp. 4/1-4/7, Nov. 1999.

[6] X. Zhu, Y. Li, S. Yong, Z. Zhuang, "A novel definition and measurement method of group delay and its application," IEEE Transaction on instrumentation and measurement, Vol.58, No.1. pp. 229-233, Jan. 2009.

[7] X. Huang, M. Caron, "A novel type-based group delay equalization technique," Circuits and Systems (ISCAS), Proceedings of 2010 IEEE International Symposiumon, pp. 2836-2839. Jun. 2010.

[8] X. Hunag, M. Caron, "Type-based group delay equalization technique", GD equalizer IEEE Transactionson Circuit andSystems, Vol.58, No.7, pp. 1661-1670, Jul. 2011.

[9] S. Myoung, Y. Kim, J. Yook, "Impact of group delay in RF BPF on impulse radio systems," in Proc. 2005 IEEE MTT -SInt. Microw. Symp. Dig., pp. 1891-1894, Jun. 2005.

[10] Adel A. Saleh, "Frequency-independent and frequency-dependent nonlinear models of TWT amplifiers," IEEE Trans. Commun., Vol.29, pp. 1715-1720., Nov. 1981

\section{김 용 국 (Yongguk Kim)}

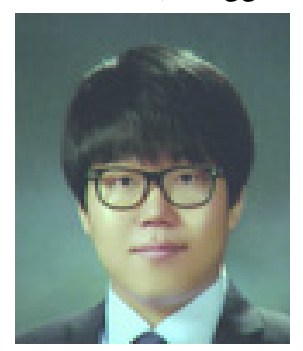

2012년 2월 충북대학교 전자 공학과 졸업

2012년 3월 현재 충북대학교

전자 공학과 석사과정

<관심분야> 무선통신시스템,

위성통신시스템
조 병 각 (Byung Gak Jo)

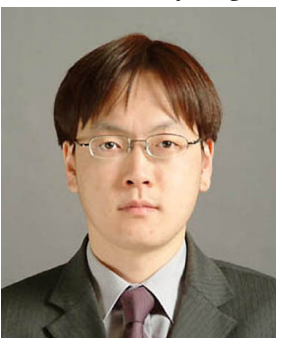

2000년 2월 아주대학교 전기전 자공학부(공학사)

2002년 2월 아주대학교 전기전 자공학부(공학석사)

2002년 1월 현재 국방과학 연구소 선임 연구원

모뎀 <관심분야> 위성 통신 시스템,

백 광 훈 (Gwang Hoon Baek)

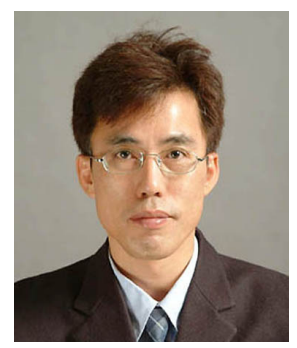

1988년 2월 경북대학교 전자 공학과(공학사)

1990년 2월 경북대학교 전자 공학과(공학석사)

1990년 1월 현재 국방과학

연구소 책임 연구원

<관심분야> 위성 통신 시스템,

네트워크, 모뎀

유 흥 균 (Heung-Gyoon Ryu)

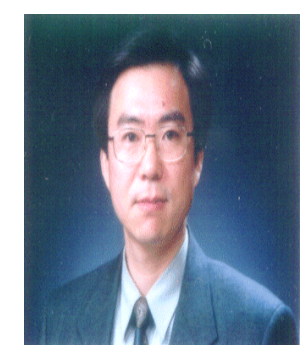

1988년 현재 충북대학교 전 자공학과 교수

2002년 3월 2004년 2월 충북 대학교 컴퓨터정보통신연구 소 소장

1996년 현재 IEEE, IET 논 문 심사위원

2002년 한국전자파학회 학술상 수상

2008년 ICWMC 2008 국제학술대회 "Best Paper Award'수상

<관심분야> 무선 통신 시스템, 위성통신, B3G/4G 이동통신 시스템, 통신회로 설계 및 통신 신호 처리 